Business and Economics Research Journal

Volume 9 Number 12018

pp. $151-167$

ISSN: $1309-2448$

DOI Number: 10.20409/berj.2018.97

\title{
İyi Bir Asker Mi? İyi Bir İllüzyonist Mi? Kariyerizm ile Zorunlu Vatandaşlık Davranışları Arasındaki İlişside İşten Ayrılma Niyetinin Rolü
}

\author{
Bora Yıldız $\quad$ Özlem Ayaz Arda ${ }^{\mathrm{a}}$
}

Öz: Bu çalışmada kariyerizm eğiliminin zorunlu vatandaşlık davranışları üzerindeki etkisi ve işten ayrılma niyetinin bu ilişki üzerindeki şartlı etkisi incelenmiştir. Araştırmanın amacı, birey düzeyindeki bir eğilim olan kariyerizmin, zorunlu vatandaşlık davranışları üzerindeki etkisini ve işten ayrılma niyetinin bu ilişki üzerindeki şartlı değişken etkisinin olup olmadığını saptamaktır. Araştırma Istanbul'da görev yapan 330 özel banka çalışanı üzerinde uygulanmıştır. Kolayda örnekleme yöntemi ile elde edilen veriler açıklayıcı faktör analizi, korelasyon analizi, güvenilirlik analizi ve şartı değişkenin farklı seviyeleri hakkında detaylı bilgi veren SPSS PROCESS makrosu kullanılarak hiyerarşik regresyon analizleri ile test edilmiştir. Araştırma bulguları göstermektedir ki, kariyerizm eğilimi zorunlu vatandaşlık davranışlarının istatistiksel açıdan anlamlı ve olumlu bir yordayıcısıdır. Bununla beraber, işten ayrılma niyetinin bu ilişki üzerindeki şartlı etkisi istatistiksel açıdan anlamlıdır. Buna göre, işten ayrılma niyetinin düşük olduğu durumda kariyerizm ile zorunlu vatandaşlık davranışları arasındaki ilişki daha güçlüdür. Ayrıca araştırma sonuçları ışığında araştırmacılar ve uygulayıcılar için çeşitli teorik ve pratik öneriler sunulmuştur.

Anahtar Sözcükler: Kariyerizm, Zorunlu Vatandaşlık Davranışları, İşten Ayrılma Niyeti

JEL Sınıflandırması: M10, M12, D23, O15

\section{Being a Good Soldier or an Illusionist? The Role of Turnover Intention on the Relationship between Careerism and Compulsory Citizenship Behaviors}

\begin{abstract}
In this study, the moderating effect of turnover intention on the relationship between careerism and compulsory citizenship behaviors was investigated. The purpose of the study is to determine the effect of careerism, as an individual level orientation, on the compulsory citizenship behaviors, and the moderating effect of turnover intention on this relationship. Accordingly, the study was conducted on the 330 bankers, who work in private banks in Istanbul. Data were gathered by using convenient sampling method with survey technique. The data were analyzed with exploratory factor analysis, correlation analysis, and hierarchical regression analysis by using SPSS along with PROCESS which is a macro for examining different levels of moderator variable, developed for the test of complex relations among the multiple variables. Findings indicate that careerism is one of the positive and statistically significant predictors of compulsory citizenship behaviors. Moreover, the moderating effect of turnover intention on the careerism-compulsory citizenship behaviors relationship is also statistically significant, such that the positive effect of careerism on the compulsory citizenship behaviors is stronger when the level of turnover intention is low. Managerial and practical implications, as well as further research directions, are provided which will be deemed as useful both for academicians and industry professionals.
\end{abstract}

Keywords: Careerism, Compulsory Citizenship Behaviors, Turnover Intention

JEL Classification: M10, M12, D23, O15

Asst. Prof., PhD., Istanbul University, Faculty of Economics, Department of Business Administration, Istanbul, Turkiye, borayildiz@istanbul.edu.tr (ORCID ID: 0000-0002-0373-6457)

${ }^{b}$ Asst. Prof., PhD., Bahcesehir Cyprus University, Faculty of Economics, Administrative and Social Sciences, Department of Business Administration, Nicosia, Northern Republic of Cyprus, ozlem.ayazarda@cyprus.bau.edu.tr (ORCID ID: 0000-0002-2836-6317) 
İyi Bir Asker Mi? İyi Bir illüzyonist Mi? Kariyerizm ile Zorunlu Vatandaşlık Davranışları Arasındaki İlişkide İşten Ayrılma Niyetinin Rolü

"Herşey göründüğü gibi değildir. Tuz bile ilk bakışta şeker gibi görünür" Anonim.

\section{Giriş}

Örgütsel vatandaşlık davranışları (ÖVD) otuz yıldan fazla süredir yönetim alanyazında oldukça rağbet görmüş bir kavram olarak karşımıza çıkmaktadır. Genel bir anlatımla ÖVD, kurumun etkin bir sosyal çevre sağlamasına yardımcı olan ve çalışanlar tarafindan gönüllülük esasına dayanılarak gösterilen rol ötesi davranışlar bütünüdür (Smith vd., 1983; Organ, 1997). Ortaya atıldığı dönemden itibaren ÖVD, kurumların işleyişi ve iş sonuçları açısından birçok çalışmada olumlu bir yapı olarak görülmüştür (Organ ve Konovsky, 1989; Organ, 1988; 1990; Organ ve Lingl, 1995; Podsakoff ve McKenzie, 1994; Le Pine vd., 2002; Podsakoff vd., 2009). Ancak konu ile ilgili araştırmalar ilerledikçe, gönüllülük esasına dayanan ÖVD’nin yapısının değiştiği ve kurumlar ve yöneticileri tarafindan istenen bazı davranışların görev tanımı içinde mi yoksa dışında mı olduğu tartışmalarının başladığı görülmüştür (Morrison, 1994). Akabinde ise ÖVD olarak tanımlanan davranışların, bazı kurumlarda görünürde gönüllülük esasına göre yapıldığı ortaya çıkmıştır. Başka bir söylemle gönüllü davranışların sanki çalışanların görevinin bir parçasıymış gibi görünmesi, zorunlu vatandaşıı davranışları (ZVD) (compulsory citizenship behaviors) kavramının ortaya atılmasına neden olmuştur (VigodaGadot, 2006, 2007; Bolino vd., 2010; Dalal, 2005).

ZVD ile ilgili alanyazındaki çalışmalar incelendiğinde şimdiye kadar yapılan çalışmaların çoğunlukla kurumsal politikalar (Vigoda-Gadot, 2007), performans baskısı (Alkan ve Turgut, 2015) ve özerk çalışma ortamının olmaması (Vigoda-Gadot, 2007) gibi kurum düzeyindeki faktörlere odaklandığı gözlenmektedir. Ancak, alanyazında bu davranışların birey düzeyindeki öncülleri ile ilgili çalışmalar oldukça sınırlıdır. ZVD'nin çalışanlar üzerindeki olumsuz sonuçlarına bakıldığında iş-aile çatı̧̧ması, iş-serbest zaman çatışması, iş stresi, işten ayrılma niyeti gibi (Bolino ve dig., 2010) sonuçlarla beraber bu sonuçlara ÖVD baskısının sebep olduğu (Liu vd., 2017) geçmiş çalışmalarca ortaya konmuştur. Ancak her ne kadar ortaya konan olumsuz sonuçlar ZVD'nin olumsuz bir doğaya sahip olduğunu gösterse de ZVD'nin yapısını tam olarak anlamak adına yeni çalışmalara ihtiyaç olduğu düşünülmektedir. Bu bağlamda ZVD'nin öncüllerini belirlemeye yönelik çalışmaların yapılması bu davranışların kurumlar tarafindan etkili bir şekilde yönetilmesi ve varlıkları hakkındaki farkındalığın oluşması açısından önem arz etmektedir.

Örgütsel davranış alanındaki davranışların birey düzeyindeki öncüllerini belirlemeye yönelik çalışmalar çoğunlukla tutumlar, duygular, duygu durumları, kişilik, değerler, algılar üzerine odaklanmaktadır (Robbins ve Judge, 2013). Bu değişkenlerden biri olan kişilik özellikleri birey düzeyindeki değişkenlerden biridir. Kişiliği ölçmekte kullanılan birçok yöntem kişiliği tanımlamakta çok faktörlü bir yapı sergilemektedir. Bu karmaşıklığı basite indirgemek adına Beş Büyük (BigFive) kişilik modeli diğer birçok özelliği özetleyen yaygın bir ölçüm metodudur (Robbins ve Judge, 2013). Her ne kadar bu yapı ilgili alan yazında oturmuş bir yöntem olsa da Beş Büyük kişilik özelliğinin yanında makyavelizm, narsisizm, proaktif kişilik özelliği gibi kişilik özelliklerinin de alanyazında ele alındığı söylenebilir (Robbins ve Judge, 2013). Ancak ilgili alanyazın incelendiğinde bu değişkenlerden bir diğerinin de kariyerizm olduğu söylenebilir (Feldman ve Weitz, 1991). Kariyerizm (careerism), çalışanların kariyer ilerlemelerini yasal yöntemlerden uzak yöntem ve usullerle, performansa dayalı olmayan bir şekilde sürdürme eğilimi olarak tanımlanmaktadır (Feldman ve Weitz, 1991). Tanımdan da anlaşılacağı üzere, bu eğilimin birey düzeyindeki olumsuz bir değişken olduğu söylenebilir. Bu düşünceyi destekleyen pek çok çalışmaya alanyazında rastlanılmaktadır. Örneğin; Yıldız vd.'nin (2015) yapmış oldukları çalışmada kariyerizmin olağan dışı iş yeri davranışlarının (üretkenlik karşıt iş yeri davranışları, sapkın iş yeri davranışları) olumlu bir yordayıcısı olduğu bulgulanmıştır. Bu bağlamda kariyerizm' in olumsuz işyeri davranışlarından biri olan ZVD üzerinde nasıl bir etkiye sahip olacağı sorusu bu çalışmanın temel araştırma sorusunu teşkil etmektedir.

Yukarıdaki açıklamalar ışı̆̆ı altında bu araştırmanın amacı;

a) Kariyerizm eğiliminin örgütsel davranış alanında yaklaşık 10 yıllık bir geçmişe sahip olan ve gerek ulusal gerekse uluslararası alanyazında son zamanlarda gittikçe önem kazanan ZVD üzerindeki etkisini Sosyal Bilişsel Teori (Social Cognitive Theory) kapsamında incelemek ve

b) işten ayrılma niyetinin bu ilişki üzerindeki şartlı değişken etkisinin olup olmadığını saptamaktır. 
Bu açıklamalar dahilinde kariyerizm eğilimine sahip çalışanların işten ayrılma niyetinin varlığı durumunda zorunlu vatandaşlık davranışları sergileme potansiyellerinin belirlenmesi amaçlanmıştır. Bu doğrultuda çalışmanın akışı şu şekildedir; öncelikle araştırmaya dayanak olan Sosyal Bilişsel Teori kuramsal çerçeve başlığı altında sunulmuş, ardından kariyerizm değişkeninin kavramsal açıklamasına yer verilmiştir. Sonrasında örgütsel vatandaşlık davranışlarından (ÖDV), zorunlu vatandaşlık davranışlarına (ZVD) giden yolda ÖVD ve ZVD arasındaki ilişki ortaya konmuş, işten ayrıma niyetinin bu ilişki üzerindeki şartı etkisi tartı̧ıımıştı. Son olarak araştırma metodolojisi ve bulgular ortaya konmuş, sonuç ve öneriler başlığı altında araştırma sonuçları, ilgili alanyazın ve teorik dayanaklarla mukayeseli olarak tartş̧ımıştır.

\section{Kuramsal Çerçeve}

Bu çalışmada test edilmesi amaçlanan ve ilgili alanyazındaki çalışmaların bir sonucu olarak geliştirilen araştrrma modeli Sosyal Bilişsel Teoriye dayanarak açıklanmıştır. Sosyal bilişsel teori (social cognitive theory) (SBT), öğrenmenin sosyal bir ortamda, kişinin çevresiyle dinamik ve karşılıklılık esasına dayanan belli başı etkileşimler sonucunda oluştuğunu ileri sürmektedir (Bandura, 1986). SBT kişilerin sosyal etkilenme, iç ve dış sosyal ortamların getirdiği destekler (reinforcement) sonucu belli başıl bilişsel kalıplar gerçekleştirdiklerini ve bu kalıplarını davranışlara dönüştürdüklerini belirtir. Diğer bir deyişle, bireyler sosyal çevrelerini de dikkate alarak davranışlarını oluştururlar. Kişilerin geçmiş deneyimleri davranışlarını etkileyen önemli faktörlerden biridir ve geçmiş deneyimler kişilerin beklentilerini, umutlarını, destek verme ve alma kalıplarını da etkilerler. Tüm bunların sonucunda bireylerin belli başlı davranışları neden ve nasıl sergiledikleri cevap bulmaktadır. Sonuç olarak, SBT bireylerin amaçlarına yönelik olarak, davranışlarını kontrol ve destek yoluyla nasıl ayarladıklarını ve bu davranışların zaman içinde nasıl değişebileceğini açıklamaya çalışır. Kariyeristler çalıştıkları ortamlardaki sosyal ilişkilerini kullanarak performansa dayalı olmayan bir kariyer planını takip etmeye meyillidirler. Bu sebeple kariyerist çalışanların, yöneticilerinin ya da iş arkadaşlarının beklentilerine uygun ancak gönüllü olmayarak sergiledikleri davranışlar söz konusu olabilmektedir. Böylece kariyerist çalışanların zorunlu vatandaşlık davranışları sergileyecekleri öngörülmektedir.

Bu teorik dayanaklara binaen kariyerist çalışanların, gerek iş etiği ve ahlak kuralları gerekse psikolojik sözleşmeye aykırı olduğu halde, yöneticilerinin ya da iş arkadaşlarının beklentilerine uygunmuş gibi gözüken ama aslında gönüllü olmayan zorunlu vatandaşlık davranışları sergileyecekleri öngörülmektedir.

\subsection{Kariyerizm}

Kariyerizm (careerism), çalışanların kariyer ilerlemelerini yasal yöntemlerden uzak metot ve usullerle sürdürme eğilimi olarak tanımlanmaktadır (Feldman ve Weitz, 1991). Alanyazında uç kariyerizm (extreme careereism) olarak da geçen bu kavram çalışanların güç, itibar kazanmak ve kariyerlerini ilerletmek için görev performanslarının dışında kalan görünüşte olumlu veya olumsuz olabilecek davranış ve eylemlerde bulunmalarıdır (Bratton ve Kacmar, 2004). Kariyerist eğilime sahip çalışanların kariyer ilerlemeleri için gerekli performansı sağlamaktan ziyade başarılıymış gibi görünme ve gerek iş arkadaşları gerekse yöneticileri ile iyi ilişkiler kurmayı kariyer ilerlemeleri için bir araç olarak kullanma gibi eğilimleri vardır (Feldman ve Weitz, 1991). Yıldız ve Alpkan (2015) ile Yıldız vd. (2015)'in yapmış olduğu çalışmalara göre de kariyerizm eğilimine sahip çalışanlar gerek kuruma gerekse kurum çalışanlarına karşı üretkenlik karşıt iş yeri davranışları sergilemektedirler. Benzer şekilde alanyazındaki çalışmalar kariyerizm ile örgütsel vatandaşlık davranışları (Adams, 2011) ve örgütsel güven (Aryee ve Chen, 2004) arasında olumsuz, işten ayrılma niyeti ile olumlu (Adams, 2011) bir ilişki olduğunu vurgulamaktadır. Ayrıca Chiaburu ve arkadaşları (2011) yapmış oldukları çalışmada duygusal dengesizlik ve psikopati eğilimi olan ve karşılıklııık esasını daha az dikkate alan bireylerde kariyerizmin daha fazla görülebileceğini bulgulamıştır.

Kariyerizm eğilimine sahip çalışanların, içinde bulundukları kurumların genel performansına zarar verecek düşük iş performansı ve daha fazla işten ayrılma oranları sergilemeleri söz konusudur (Feldman ve Weitz, 1991). Çünkü kariyerizm eğilimine sahip çalışanların bağlamsal ve görev performanslarına odaklanmak yerine, bunlarla ilgili olmayan, sırf kendi çıkarlarına yönelik davranışlara yönelmeleri söz konusu olabilmektedir (Chiaburu vd., 2013). Kariyerizm eğilimli çalışanların yaşadığı bir diğer durum ise, kendi kişisel amaçları ile kurumun amaçları arasında kalmaları ve tutarsızık yaşamalarıdır (Chay ve Aryee, 1999; Feldman 
ve Weitz, 1991; Chibauru vd., 2013). Ayrıca, çalışanların, iş güvencelerinin azaldığı ve yönetimin kendilerine nasıl bir tutum ve davranış içinde olacağını bilmedikleri çalışma şartlarında da kariyerist bir eğilim sergiledikleri gözlemlenmiştir (Chay ve Aryee, 1999). Diğer yandan, yapılan bazı çalışmalarda iş yerlerinin uygun gelişme ve kariyer ortamları sunduklarında bunun çalışanlar üzerinde olumlu etkileri olabileceği bulgulanmıştır. Örneğin Kraimer ve arkadaşları (2011), çalışanlara uygun kariyer firsatları sunulması ile iş performansları arasında olumlu ve önemli bir ilişki olduğuna dikkat çekmektedir. Nihayetinde, kurumların çalışanları için işlevsel ve kişiye yönelik, çalışanı tatmin edebilecek kariyer planları yapamıyor olması, kariyerizm amacı güden çalışanlara zemin hazırlanmaktadır (Crawshaw vd., 2012). Ancak, birçok kurumun çalışanlarıyla mutabık kaldığı işlevsel bir kariyer planı olmamasının çalışanların örgütsel bağlıığını düşürdüğü bilinmesine rağmen (Blau vd., 2001) çok az kurumun bu konuyu dikkate alıyor olması konunun öneminin henüz net olarak anlaşılmadığını düşündürmektedir. Bu çalışmalara ek olarak diğer araştırmalar, çalışanların, iş ortamlarında belirsizliğin yüksek olduğu, belli bir kariyer planlarının olmadığı veya bu planları kendileri için tatmin edici bulmadıkları zaman kendi kariyerlerini kendileri planlama yoluna gittiklerini ortaya koymuştur (Chay ve Aryee, 1999). Bu sebeple genel olarak kariyer gelişim firsatlarının, kariyerizm eğilimine bağlı davranışların en önemli öncüllerinden biri olduğu söylenebilir.

\subsection{Zorunlu Vatandaşlık Davranışları}

Zorunlu vatandaşlık davranışlarını (ZVD) daha iyi anlatmak için öncelikle kısaca örgütsel vatandaşlık davranışlarını (ÖVD) ele almak faydalı olacaktır. ZVD, ÖVD gösteren çalışanların niyetleri, motivasyonları ve elde ettikleri sonuçlar detaylı olarak incelendiği zaman ortaya çıkmış bir kavramdır (Zhao vd., 2014).

ÖVD'nin ilk kapsamlı tanımı, kurumun performans ve buna bağlı olarak verdiği prim ve ödül sistemlerince doğrudan tanınmayan ancak bir bütün olarak ele alındığında kurumun faaliyetlerini verimli ve etkin olarak gerçekleştirmesine yardım eden, çalışanların kendi takdirlerine bağlı davranışlar bütünü olarak yapılmıştır (Smith vd., 1983). Ancak bu tanım 1997 yılında Organ'ın yaptığı kapsamlı çalışmalar sonucunda "görev performansını destekleyen, iş yerinin sosyal ve psikolojik ortamlarının devamına ve gelişimine katkıda bulunan davranışlar" olarak genişletilmiştir (Organ, 1997: 86). ÖVD’nin kurumlardaki sonuçları ile ilgili geçen otuz yıllık dönemde birçok araştırma yapılmıştır. İlgili alanyazın incelendiğinde geçmiş araştırmaların ÖVD ile ilgili birçok öncül ve sonuçlara odaklandığı gözlenmektedir. Çalışan motivasyonu (Organ, 1990), dönüşümsel liderlik, güven ve çalışan tatmini (Podsakoff vd., 1990) ÖVD'nin ilişkisinin incelendiği ana kavramlardır. Bunun yanında, ÖVD'nin tutumsal ve yaradılışsal yordayıcıları (Organ ve Ryan, 1995), boyutları (LePine vd., 2002), örgüt ve birey genelindeki yansımaları (Podsakoff vd., 2009), kavramın gelişmesini ve derinleşmesini sağlamıştır. Ayrıca iş tatmini, duygusal kararsızlık ve duygular (Ziegler vd., 2012), ÖVD ve zararlı iş davranışları (Dalal, 2005) ve hizmetkar liderlik ve adalet (Walumbwa vd., 2010), yine ÖVD'nin incelendiği belli başlı örgütsel davranış alanyazınındaki konular olarak karşımıza çıkmaktadır. Son dönemde yapılan araştırmalara göre ise ÖVD'nın etkileri daha derinlemesine incelenmeye başlamış ve kurumun içinde gösterilen her davranışın ÖVD olarak kabul edilip edilmediği de tartışma konusu haline gelmiştir (Vigoda-Gadot, 2006; 2007; Koopman vd., 2016). Çalışanların görev tanımları kapsamındaki davranışları ile gönüllü yaptıkları ancak rol dışı olumlu davranışlar arasında çok ince bir çizgi vardır (Morrison, 1994). Bu sınırın doğru olarak belirlenmemesi çalışanların sömürülmelerine ve suistimal edilmelerine sebebiyet verebilir (Vigoda-Gadot, 2006).

Alanyazında ZVD, çalışanın kendi iradesi ve takdiri ile gösterilen geleneksel örgütsel vatandaşlık davranışlarının aksine çeşitli baskılar sonucunda ortaya çıkan ve ÖVD’nin karanlık ve yıkıcı yönü olarak tanımlanmaktadır (Vigoda-Gadot, 2006; 2007). Başka bir ifadeyle ÖVD gönüllülük esasına dayanır ancak bu tip rol ötesi davranışların her zaman gönüllü ve isteyerek yapılmadığı söylenebilir. ÖVD ile ZVD arasındaki en önemli fark ÖVD'nın "doğal” ve içten gelerek" gösterilmesi, ZVD'nın ise bu içtenlik ve doğallıktan uzak olması ve zorunluluktan dolayı gösterilmesi olarak belirtilebilir (Vigoda-Gadot, 2006). ZVD, kurum içinde belli bir hiyerarşiye ve otoriteye sahip bireylerin, alt seviye çalışanlarına baskı uygulayarak karşı koyamayacakları bir şekilde istediklerini yaptırmaları ile de ortaya çıkmaktadır (Vigoda-Gadot, 2006). Örnek olarak, maliyetleri azaltmak adına ön büro çalışanlarının görev sorumluluklarının dışında olan işleri de onlara yaptırmak gösterilebilir. Ya da kurumun sosyal sorumluluk gibi ana görevi dışındaki konularla ilgili toplantlarına izin 
günlerine denk gelmesine rağmen çalışanları bu toplantılara katılmaya zorlamak gibi durumlar gösterilebilir. Bazı çalışanlar bu tip baskılardan gerek performans gerekse psikolojik açıdan oldukça olumsuz etkilenebilirler ve vicdanlılık, centilmenlik, nezaket, sivil erdem gibi daha önceden gösterdikleri ÖVD'leri artkk sergilemekten vazgeçebilirler (Vigoda-Gadot, 2007). Ayrıca, çalışanlar yöneticilerinden gelen bir isteği karşılayamadıklarında rahatsızlık duymakta ve bu durumun sonradan kendilerine sorun yaratabileceğinden korkmaktadırlar (Vigoda-Gadot, 2007). Başka bir ifadeyle, yöneticilerden gelen ve çalışanları rol dışı davranışlarda bulunmaya teşvik eden istekler zorunlu tutulmasa bile çalışanlar isteği yerine getirmedikleri için yöneticilerine karşı güvensizlik hissedebilmektedirler.

Gerek ÖVD olarak görülen davranışların kurum içinde gayri resmi olarak ödüllendirilmeleri, gerekse çalışanlara uygulanan çeşitli baskı ve dayatmalar sonucunda da ZVD ortaya çıkabilmektedir (Bolino vd., 2010). Ayrıca çalışanların ÖVD göstermedikleri takdirde cezalandırılacakları inancının olması da söz konusudur (Salamon ve Deutsch, 2006). Bu açıdan, rol ötesi davranışların olumsuz yönlerinin fark edilmesi dikkatleri ZVD'ye çekmiştir. Tüm bunların sonucu olarak da çalışanlar zorlandıkları, sömürüldükleri ve suistimal edildikleri algısı taşıdıklarında ZVD gösterme eğilimi içinde olabilirler. ZVD'nin olası sonuçlarının: iş stresi, tükenmişlik, kurumsal politikalar, çalışanların işten ayrılma niyetleri ve ihmalkârlık gibi davranışlarla ilgili olabileceği tahmin edilmektedir (Vigoda-Gadot, 2006).

Alkan ve Turgut, (2015) ZVD'yi çalışanların psikolojik güven algıları ve kurum politikaları açısından incelemişler ve kurum politikalarının ZVD üzerinde olumsuz olarak etkili ve önemli olduğunu bulgulamışlardır. ZVD gösteren çalışanların öncelikle ÖVD göstermeleri konusunda üzerlerinde baskı hissettikleri belirtilmiştir. İkinci olarak ise, çalışanların ailelerine karşı duydukları sorumluluk nedeni ile kendilerini ÖVD göstermek zorunda hissetmeleri çalışmanın bir diğer dikkat çekici sonucudur. Zhao vd. (2014) ise, ÖVD ile ZVD arasındaki ilişkinin çalışanların kurumları ile ne derece özdeşleştikleri ve dolayısıyla ÖVD'den ZVD'ye doğru giden sürecin çalışanların benlik algıları ile ilişkili olduğunu belirtmişlerdir. Buna göre ZVD gösteren çalışanların kurum ile özdeşleşmelerinin yok olduğu, böylelikle rol ötesi davranışları daha az sergiledikleri ortaya konmuştur. Ayrıca bu çalışmada, kurum içindeki etkileşimsel adaleti daha düşük seviyede algılayan çalışanların ZVD göstermelerinin daha yüksek olasılık taşıdığı üzerinde durulmuştur. İstismarcı yöneticilerin (abusive managers) ZVD üzerinde doğrudan etkilerinin bulunduğu diğer bir araştrmaya göre (Zhao vd., 2013) istismarcı yönetim biçimini benimseyen yöneticilerin, çalışanların rollerinin dışında kalan ve gönüllü olabilecekleri davranışları göstermekten kaçındıkları belirtilmiştir. Böylelikle, bu araştırmaya göre istismarcı yönetici davranışlarının ZVD’nin yordayıcısı olması söz konusudur. Ancak bu davranışlar ile ilgili teorik ve deneysel araştırmalar hala sınırlı düzeydedir.

\section{Değişkenler Arası iliş̧kiler}

\subsection{Kariyerizm ile Zorunlu Vatandaşık Davranışları Arasındaki ílişki}

Bir önceki bölümdeki açıklamalarda da görüldüğü üzere, kariyerizm amacı güden çalışanlar kurumları tarafindan sağlanmış olsa bile kendileri için yapılmış kariyer planlarıyla ilgilenmektense kendi kişisel çıkarlarının izinde gitmeyi seçmektedirler. Sosyal Bilişsel Teori (Bandura,1986; Bandura vd., 1996; 1999) bireylerin düşünce ve davranışları üzerinde kontrol gücüne sahip olduklarını vurgulamaktadır. Buna göre bireylerin zihinlerinde iki mekanizma vardır bunlardan biri öz düzenleyici (self regulatory) sistem, diğeri ise kendini kınama (self condemnation) sistemidir. Öz düzenleyici sistem kişinin doğuştan itibaren edinmiş olduğu ahlaki ilke ve standartların oluşturmuş olduğu bir veri tabanı gibidir. Bu anlamda birey belirli bir davranışa geçmeden önce ilgili eylem bu mekanizmanın değerlendirmesinden geçmelidir. Diğer yandan kendini kınama sistemi ise, öz düzenleyici sistemden geçmesi uygun olmayan davranış ve eylemleri engelleyici (frenleyici) mekanizmadır. Bu anlamda eğer birey öz düzenleyici mekanizmayı devreye sokmazsa dolaylı olarak kendini kınama sistemini de devre dışı bırakmış olmaktadır. Başka bir söylemle eğer kişi uygun olmayan eylemleri kendi çıkarı doğrultusunda öz düzenleyici mekanizmayı çalıştırmayarak kendince haklı çıkarırsa, dolayısıyla kendini kınama sistemini de devre dışı bırakacak ve yapmış olduğu olumsuz eylemlerden herhangi bir rahatsızlık duymayacaktır. 
Kariyerizm eğilimi kurumlarda düşük performans, örgütsel güvenin azalması, duygusal düzensizlik gibi olumsuz sonuçlar ile ilişkilidir (Chiaburu vd., 2013; Aryee ve Chen, 2004). Bunlara ek olarak, kariyerizm ayrıca kişisel amaçları kurumsal amaçlarının üzerinde tutma, üretkenlik karşıt iş yeri davranışları sergileme gibi değişkenler ile de olumlu yönde ilişkilidir (Feldman ve Weitz, 1991; Chiaburu vd., 2011; Yıldız vd., 2015). Bu açıklamalar ışığı altında kariyerizm eğilimine sahip çalışanların olumsuz bir çalışan davranışı olan zorunlu vatandaşlık davranışlarını sergilemeleri muhtemeldir.

Yukarıdaki teorik açıklamalar ve önceki araştırma sonuçları ışı̆ında bu çalışmada kariyerizm eğilimine sahip çalışanların kariyer ilerlemelerini sürdürmek için öz düzenleyici ve kendini kınama sistemlerini devre dışı bırakma potansiyeline sahip oldukları düşünülmektedir. Bu kişiler kariyer hedeflerine ulaşmak için gerek yöneticiler gerekse de çalışanların gözünde gönüllü olmasalar dahi yardımsever ve kurumun yararına davranan kişiler olarak kendilerini lanse edebilmektedirler. Ayrıca, kariyeristler kendileri için daha kısa vadeli çözümlere odaklanma eğiliminde oldukları için ÖVD gibi uzun vadeli sonuçları olan bir davranış türünü tercih etmeyebilirler (Adams, 2011). Dolayısıyla, kariyerist kişilerin zorunlu vatandaşlık davranışlarını sergileyebilme potansiyeline sahip oldukları düşünülmektedir. Gerek teorik gerekçeler gerekse önceki çalışmaların bulgularına binaen geliştirilen araştırmanın birinci hipotezi şöyledir;

\section{H1: Kariyerizm' in zorunlu vatandaşlık davranışları üzerinde olumlu bir etkisi vardır.}

\section{2. Şartlı değişken etkisi: işten ayrılma niyeti}

Tett ve Meyer (1993) işten ayrılma niyetini bireyin kasıtlı ve bilinçli olarak kurumda kalmak istememesi olarak tanımlamaktadır. İşten ayrılma niyeti çalışanların diğer iş seçeneklerini değerlendirmeleri ile yakından ilgili olduğu için (Mobley vd., 1979), çalışan devir hızını etkileme potansiyeline sahiptir (Griffeth ve Hom, 1995). Bu sebeple işten ayrılma niyeti kurumlarından çalışanlarından görmeyi istemedikleri eğilimlerden biridir. ilgili alanyazında bu görüşü destekleyen birçok çalışmaya rastlamak mümkündür. Bu çalışmalara örnek olarak Egan vd. (2004) işten ayrılma niyeti ile örgütsel bağlılık ve öğrenen örgüt kültürü arasında olumsuz yönde ilişkiler bulgulamıştır. Schwepker (2001) örgütsel bağılık, etik iklim ve iş tatmini ile işten ayrılma niyeti arasında olumsuz ve anlamlı ilişkiler bulgulamıştır. Chen vd. (1998) işten ayrılma niyeti ile örgütsel vatandaşlık, örgütsel bağlıık, iş tatmini arasında ilişkiler bulmuştur. Benzer şekilde Meyer vd. (2002) örgütsel bağılık ile işten ayrılma niyeti arasında olumsuz ilişkiler olduğunu bulgulamıştır. Bu çalışmalara ek olarak alanyazındaki birçok çalışma davranışsal eğilimlerin işten ayrılma niyetinin ortaya çıkmasında önemli öncüller olduğunu vurgulamaktadır (Lee ve Mowday, 1987; Abrams vd., 1998). Ancak bu görüşün aksine kariyeristler yüksek düzeyde kariyer basamaklarını trrmanma motivasyonuna sahip olduklarından, bu kişilerin bir takım izlenim yönetimi taktikleri sergilemeleri söz konusu olabilir. Başka bir ifadeyle kariyerist kişiler işten ayrılma niyeti yerine mevcut işlerinde kalarak ve sabır göstererek istedikleri amaca ulaşma eğilimindedirler. Sosyal Bilişsel Teori, kişilerin davranışları sonucunda belli bir beklenti içinde olduklarını söyler. Bu sebeple kariyerizm gösteren çalışanların kurum içindeki konumları ile ilgili belli bir avantaj elde etme beklentileri vardır. Bu bağlamda kariyerizm ile işten ayrılma niyeti arasında olumlu yönde bir ilişki olmayacağı düşünülmektedir. Başka bir söylemle, kişi kariyerizm eğilimine sahip oldukça işten ayrılma niyetinin azalacağı düşünülmektedir. Bu açıklamalar ışığında kariyerizm ile zorunlu vatandaşık davranışları arasındaki bu olumlu ilişkinin işten ayrılma niyeti düşük olan çalışanlarda daha güçlü olacağı öngörülmektedir. Buna göre geliştirilen şartlı değişken hipotezi şöyledir;

H2: Kariyerizm ile zorunlu vatandaşlık davranışları arasındaki olumlu ilişki işten ayrılma niyeti düşük olan çalışanlarda daha güçlüdür. 
Şekil 1. Kavramsal Model

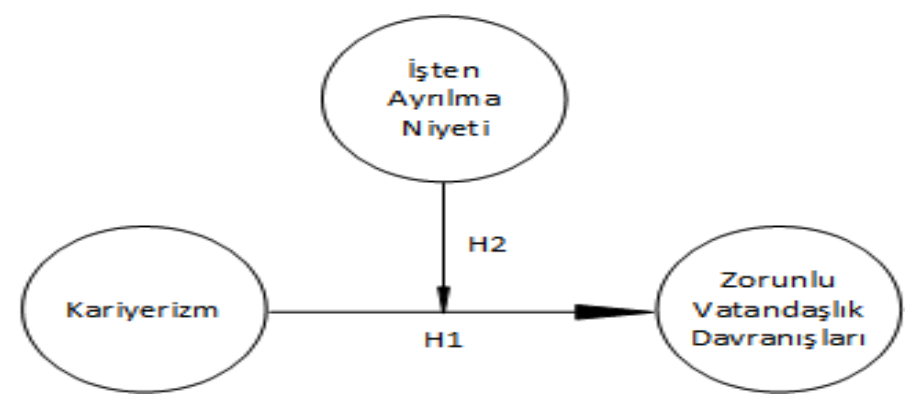

\section{Yöntem}

Anket sonuçlarının değerlendirilmesinde SPSS 21.0 istatistik paket programı kullanılmıştır. Kariyerizm, zorunlu vatandaşlık davranışları ve işten ayrılma niyeti arasındaki ilişkilerin belirlenmesine yönelik anket çalışması doğrultusunda elde edilen verilerin analizinde öncelikle katılımcıların demografik özellikleri sınıflandırılmış, daha sonra değişkenler arası birlikte değişim ilişkileri korelasyon analizi, kariyerizmin zorunlu vatandaşlık davranışları üzerindeki etkisini test etmek için basit doğrusal regresyon analizi yapılarak incelenmiştir. Son olarak işten ayrılma niyetinin şartlı etkisinin hangi seviyelerde (düşük, orta, yüksek) kariyerizm-zorunlu vatandaşlık ilişkisini etkilediğini test etmek için PROCESS makrosunda hiyerarşik regresyon analizi yapılmıştır.

\section{1. Örneklem}

Kolayda örnekleme yöntemi ile özel sektördeki 330 (191 erkek, 139 kadın) banka çalışanından anket tekniğiyle veri toplanmıştır. Bankacılık sektörü: "Rekabetin yoğun olduğu, uzun çalışma saatlerine sahip, fazla mesainin çok sık ve fazla görüldüğü, özel hayatın sınırlandırıldığı ve baskılandığı bir sektör halini almıştır" (Karataş, 2013 s: 8). Bu düşünceden hareketle banka çalışanlarının örneklem olarak seçilmesindeki temel gerekçelerden biri bankacılık sektöründe genel olarak kariyer gelişim firsatlarının mümkün olmasıdır. Katılımcıların büyük bir çoğunluğu erkek (191 kişi, \%58), 32-45 yaş aralığında (135 kişi \%41), medeni durumu evli (222 kişi, \%67) lisans mezunu (144 kişi, \%44) ve 1- 5 yıl aralığında (216 kişi, \%65) mesleki deneyime sahip banka çalışanlarından oluşmaktadır. Örneklem dağılımı Tablo 1'de sunulmuştur.

Tablo 1. Örneklem Dağııımı

\begin{tabular}{|c|c|c|c|c|c|}
\hline Cinsiyet & Sayı & $\%$ & Eğitim Durumu & Sayı & $\underline{\%}$ \\
\hline Kadın & 139 & $42 \%$ & Lise & 41 & $12 \%$ \\
\hline Erkek & 191 & $58 \%$ & \multirow{3}{*}{$\begin{array}{l}\text { Yüksek Okul } \\
\text { Lisans } \\
\text { Yüksek Lisans }\end{array}$} & 49 & \multirow{2}{*}{$\begin{array}{l}15 \% \\
44 \%\end{array}$} \\
\hline \multicolumn{3}{|l|}{ Yaş } & & 144 & \\
\hline $18-31$ & 53 & $16 \%$ & & 96 & $29 \%$ \\
\hline $32-45$ & 135 & $41 \%$ & \multicolumn{3}{|l|}{ Kıdem } \\
\hline $46-50$ & 42 & $13 \%$ & \multirow{3}{*}{$\begin{array}{l}1-5 \text { yıl } \\
6-10 \text { yıl } \\
11-20 \text { yıl }\end{array}$} & 216 & $65 \%$ \\
\hline$>50$ & 100 & $30 \%$ & & 47 & $14 \%$ \\
\hline \multicolumn{3}{|c|}{ Medeni Durum } & & 31 & $9 \%$ \\
\hline Evli & 222 & $67 \%$ & \multirow{2}{*}{$>21$ yıl } & & \multirow{2}{*}{$11 \%$} \\
\hline Bekar & 108 & $33 \%$ & & 36 & \\
\hline TOPLAM & & & \multicolumn{3}{|c|}{30} \\
\hline
\end{tabular}




\section{2. Ölçekler}

Kariyerizm eğilimini ölçmek için Feldman ve Weitz (1991) tarafindan geliştirilen ve Yıldız (2015) tarafindan Türkçe güvenilirlik ve geçerlilik çalışması yapılan 7 ifadeden oluşan kariyerizm ölçeği kullanılmıştr. Zorunlu vatandaşlık davranışları ve işten ayrılma niyeti ölçeklerinin Türkçe'ye uyarlanması ise Brislin vd. (1970) tarafinda önerilen geri çeviri (back translate) yöntemi kullanılarak yapılmıştır. Buna göre zorunlu vatandaşık davranışlarını ölçmek için Vigoda-Gadot (2007) tarafindan geliştirilen ve 5 ifadeden oluşan zorunlu vatandaşık davranışı ölçeği kullanılmıştır. Son olarak işten ayrılma niyetini ölçmek için Irving vd. (1997) tarafindan geliştirilen 3 ifadeden oluşan işten ayrılma niyeti ölçeği kullanılmıştır. Araştırma kapsamındaki tüm ölçeklerdeki ifadeler, beşli Likert tipidir (1=kesinlikle katılmıyorum, 5=kesinlikle kathlıyorum). Araştırmada kullanılan ölçekler EK 1'de sunulmuştur.

\subsection{Bulgular ve yorumlar}

Araştırmada kullanılan ölçeklerin tek tek yapı geçerliliği SPSS 21.0 programı kullanılarak açıklayıcı faktör analizi ile test edilmiştir., İşten ayrılma niyeti için açıklanan toplam varyans \%87,54 (KM0=.739; Barlett $=(\mathrm{df}=3) 833.401 ; \mathrm{P}<0.001)$, zorunlu vatandaşlık davranışları için açıklanan toplam varyans \%52,34 $(K M 0=.783 ;$ Barlett $=(d f=10) 407.328 ; P<0.001)$ ve son olarak kariyerizm için \%43,76 (KMO=.739; Barlett= $(d f=10) 211.515 ; P<0.001)^{\prime}$ dir. Cronbach Alpha değerleri (Cronbach, 1951) sırasıyla $\alpha=.92, \alpha=.76, \alpha=.68^{\prime}$ dir. Elde edilen güvenilirlik seviyeleri her ne kadar istenen düzeyin üzerinde olmuş olsa da kariyerizm ölçeğinin Alpha katsayısı $\alpha=.70$ değerinin altında olduğu gözlenmiştir. Ancak belirtilen ölçek Nunnally ve Bernstein (1994) tarafindan önerilen $\alpha=.65$ değerinin üzerinde olduğundan kariyerizm ölçeğinin de yeterli düzeyde güvenilir olduğu söylenebilir (Tablo 2).

Tablo 2. Faktör ve Güvenilirlik Analizi Sonuçları

\begin{tabular}{lcccc}
\hline \multicolumn{1}{c}{ Faktörler } & $\begin{array}{c}\text { Madde } \\
\text { Sayısı }\end{array}$ & $\begin{array}{c}\text { Faktör Yük } \\
\text { Aralığı }\end{array}$ & $\begin{array}{c}\text { Açıklanan } \\
\text { Varyans }\end{array}$ & $\begin{array}{c}\text { Cronbach } \\
\text { Alpha }\end{array}$ \\
\hline İșten Ayrılma Niyeti & 3 &, $908-, 955$ & 87,540 & $\alpha=.92$ \\
$K M 0=.739 ;$ Barlett $=(d f=3) 833.401 ; P<0.001$ & & & & \\
\hline Zorunlu Vatandaşlık Davranışları & 5 &, $598-, 790$ & 52,389 & $\alpha=.76$ \\
$K M 0=.783 ;$ Barlett $=(d f=10) 407.328 ; P<0.001$ & & & & \\
\hline Kariyerizm & 5 &, $624-, 695$ & 43,760 & $\alpha=.68$ \\
$K M 0=.739 ;$ Barlett $=(d f=10) 211.515 ; P<0.001$ & & & & \\
\hline
\end{tabular}

Tablo 2'den görüldüğü üzere yapılan faktör analizi sonucunda kariyerizm ölçeğine ait iki soru (Ölçek ifadeleri makale sonundaki Ek 1'de sunulmuştur) ayrı bir faktör oluşturduğundan bu sorular adım adım analizden çıkarılarak analizler tekrarlanmış ve 4 iterasyon sonucunda Tablo 2'deki faktör çözülümüne ulaşıımıştır.

Değişkenler arasındaki birlikte değişim ilişkisini göstermek üzere yapılan Pearson korelasyon analizi sonuçları ve güvenilirlik düzeyleri Tablo 3 'de sunulmuştur. Buna göre kariyerizm ile işten ayrılma niyeti arasındaki birlikte değişim ilişkisi ( $r=-.036 ; p>0.05)$ ve işten ayrılma niyeti ile zorunlu vatandaşlık davranışları arasındaki birlikte değişim ilişkisi ( $r=-.099 ; p>0.05)$ istatistiksel açıdan anlamlı değil iken, kariyerizm ile zorunlu vatandaşıı davranışları arasındaki ilişkinin istatistiksel açıdan anlamlı ve olumlu yönde olduğu ( $r=.179$; p<0.01) saptanmıştir. 
B. Yildiz - O. Ayaz-Arda

Tablo 3. Değişkenlere İlişkin Tanımlayııı İstatistikler, Korelasyon Ve İçsel Tutarlılık Düzeyleri

\begin{tabular}{|c|c|c|c|c|c|}
\hline Değişkenler & Ort. & Std. Sapma & 1 & 2 & 3 \\
\hline Kariyerizm & 3.31 & .741 & $(0.68)$ & & \\
\hline İşten ayrılma niyeti & 2.80 & 1.126 & -.036 & $(0.92)$ & \\
\hline ZVD & 1.56 & .679 & $.179 * *$ & -.099 & $(0.76)$ \\
\hline
\end{tabular}

Kariyerizmin ZVD üzerindeki nedensel etkisi ve işten ayrılma niyetinin bu ilişkideki şartlı etkisi Hayes'in (2012; 2013) SPSS programı için geliştirmiş olduğu PROCESS makrosu kullanılarak analiz edilmiştir (Tablo 4).

Tablo 4. Kariyerizm-Zorunlu Vatandaşlık Davranışları ilişkisinde İşten Ayrılma Niyetinin Şartlı Etkisi

\begin{tabular}{|c|c|c|c|c|}
\hline Bağımsız Değişkenler & 8 & $S E$ & $t$ & $p$ \\
\hline \multicolumn{5}{|c|}{ Zorunlu Vatandaşlık Davranışları } \\
\hline Sabit & 1.553 & .037 & 42.470 & $.0000^{* * * *}$ \\
\hline Kariyerizm & .153 & .050 & 3.090 & $.0022 * *$ \\
\hline İşten Ayrılma Niyeti & -.047 & .033 & -1.432 & .1531 n.s. \\
\hline Kariyerizm x İşten Ayrılma Niyeti & -.090 & .043 & -2.084 & $.0379 *$ \\
\hline İşten Ayrılma Niyeti & Etkileşim Etkisi & $S E$ & $t$ & $p$ \\
\hline \multicolumn{5}{|c|}{ Işsten Ayrılma Niyetinin Durumsal Etkisi $=M \pm 1 S D$} \\
\hline M - 1 SD (-1.1258) Düşük & .254 & .067 & 3.8162 & $.0002 * * *$ \\
\hline M (.0000) Orta & .153 & .050 & 3.0896 & $.0022 * *$ \\
\hline M + 1 SD (1.258) Yüksek & .052 & .072 & .7235 & .4699 n.s. \\
\hline \multirow[t]{2}{*}{ Model Özeti } & $R$ & $R$-sq. & $F$ & $p$ \\
\hline & .231 & .053 & 6.1109 & $.0005^{* * *}$ \\
\hline \multirow[t]{2}{*}{ Etkileşim Etkisine Bağlı R-sq.Değiş̧imi } & R-sq. değişimi & $F$ & $d f$ & $p$ \\
\hline & .0126 & 4.3444 & 326 & $.0379 *$ \\
\hline
\end{tabular}

${ }^{* *} p<0.01 ; * * * * p<0.0001$

Kurulan regresyon modeli istatistiksel açıdan anlamlıdır ( $\left.R=.231 ; R^{2}=.053 ; F=6.1109 ; p<0.001\right)$. Analiz sonuçları olumsuz bir çalışan eğilimi olan kariyerizmin zorunlu vatandaşlık davranışlarının istatistiksel açıdan anlamlı bir yordayıcısı olduğunu göstermektedir $(\beta=.153 ; t=3.090 ; p<0.01)$. Buna göre $\mathrm{H} 1$ hipotezi desteklenmiştir. Dahası işten ayrılma niyetinin kariyerizm ile zorunlu vatandaşıı davranışları arasındaki etkisi istatistiksel açıdan anlamlıdır ( $\beta=.090 ; t=-2.084 ; p<0.05)$. Kreft vd. (1995) basit modellerde ortalama odaklıık (mean centering) yaklaşımının uygun olabileceğini önermektedir. Benzer şekilde Cohen vd. (2013) sürekli değişkenlerin hiyerarşik regresyona dahil edilmelerinden ortalama odaklılık yaklaşımının tercih edilmesinin çoklu doğrusallık (multicolienarity) problemini engelleyeceğini öne sürmektedir. Bu doğrultuda işten ayrılma niyeti ve bağımsız değişken olan kariyerizm merkezileştirilmiştir. Buna göre işten ayrılma niyeti orta $(\beta=.153$; $\mathrm{t}=3.089 ; \mathrm{p}<0.01)$ ve düşük $(\beta=.254 ; \mathrm{t}=3.816 ; \mathrm{p}<0.001)$ düzeyde olan çalışanlarda kariyerizm-zorunlu vatandaşlık davranışları arasındaki bu ilişki daha güçlüdür (Şekil 2). Diğer yandan işten ayrılma niyetinin yüksek olduğu durum söz konusu olduğunda ise belirtilen kariyerizm- zorunlu vatandaşlık ilişkisinin istatistiksel açıdan anlamlı olmaması teorik öngörüleri destekler niteliktedir. Böylelikle H2 hipotezi desteklenmiştir. Elde edilen sonuçlar değerlendirildiğinde bulguların Sosyal Bilişsel Teori (Bandura,1986; Bandura vd., 1996; 1999) ile tutarlılık gösterdiği söylenebilir.

Bu sonuçları grafiksel olarak görselleştirmek amacıyla Stone ve Hollenbeck (1989)'in ve Kreft vd. (1995)'in önermiş olduğu yöntem uygulanmıştır. Bu yönteme göre, değişkenlerin ortalamasının, bir standart sapma aşağısı ve yukarısı belirlenerek şartlı etkinin grafiği Şekil 2'de sunulmuştur. 
Şekil 2: İşten Ayrılma Niyetinin Şartlı Etkisi (Düşük)

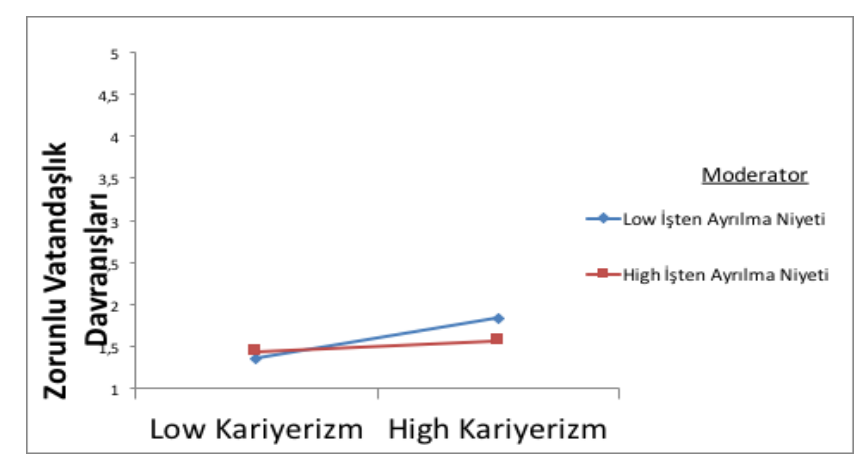

Aiken vd. (1991)'in basit eğim testine göre işten ayrılma niyetinin düşük ve yüksek seviyelerinde sıfirdan farklı değerler elde edilmiştir. İşten ayrılma niyetinin seviyelerine göre olumsuz kariyerizm ve zorunlu vatandaşlık davranışları arasındaki ilişki aynı yönde devam etmesine rağmen, düşük işten ayrılma niyetinin olmuş olduğu durumlarda hipotez 2'de iddia edildiği üzere, bu ilişkinin güçlendiğini ifade etmek mümkündür.

\section{Sonuç, Değerlendirme Ve Öneriler}

Araştırma kapsamında incelenen doğrudan (kariyerizm- zorunlu vatandaşlık davranışları) ve etkileşimsel (kariyerizm*işten ayrılma niyeti- zorunlu vatandaşık davranışı) ilişkilerin gerek ilgili alanda çalışan akademisyenlere gerekse profesyonellere faydalı olacağı düşünülmektedir. Özellikle zorunlu vatandaşıı davranışları ve kariyerizm ile ilgili alanyazının oldukça sınırlı olduğu düşünüldüğünde bu katkının daha fazla olacağı ileri sürülebilir.

Doğası itibariyle ÖVD, görev tanımının dışında ve gönüllülükle gösterilen davranışlardan oluşmaktadır. Ancak ÖVD'nin kurumlar tarafindan zorunlu kılınması, çalışanların bu davranışları istekleri dışında gerçekleştirmelerine sebebiyet vermekte böylelikle ÖVD'nın temel yapısı değişmektedir (Bolino vd., 2013). Bu noktadan hareketle çalışmada kariyerizmin ZVD'nin istatistiksel açıdan anlamlı bir yordayıcısı olduğuna dair bulgular sunulmuştur. Başka bir ifadeyle, kurumlarındaki konumlarını, çıkarları doğrultusunda görev alanları dışında kalan konuları dikkate alarak sağlamlaştırmaya çalışan bireylerin ZVD göstermeleri söz konusu olabilmektedir (Chay ve Aryee, 1999; Chiaburu, 2011).

Her ne kadar kariyerizm-ZVD ilişkisini ele alan herhangi bir çalışmaya ilgili alanyazında rastlanmamış olunsa da sosyal bilişsel teoriye dayanarak geliştirilen hipotez sonuçları teoriyi destekler niteliktedir. Bu düşüncelerle paralel olarak çalışmanın birinci hipotezi desteklenmiştir. Diğer yandan araştırmanın ikinci hipotezi olan şartlı etki yine sosyal bilişsel teoriye dayanarak geliştirilen öngörüler ile tutarlıık göstermiştir. Başka bir ifadeyle, işten ayrılma niyeti düşük olan bireylerde kariyerizm-ZVD ilişkisinin daha güçlü olduğu gözlenmiş ve böylelikle ikinci hipotez de desteklenmiştir. Burada, ZVD'nin öncülü ve yordayıcısı olan kariyerizme odaklanarak, çalışanların işten ayrılma niyetinin ne kadar güçlü olduğuna göre (durumsal etki) ZVD'na giden yol anlaşılmaya çalışılmıştr.

Illgili alanyazındaki birçok çalışma (Vigoda-Gadot, 2007; Bolino vd., 2010; Şeşen ve Soran, 2013; Johansen ve von Treuer, 2012) ZVD-işten ayrılma niyeti ilişkisinin istatistiki açıdan anlamlı olduğunu belirtse de bu çalışmada belirtilen ilişki istatistiksel açıdan anlamlı bulgulanmamıştır. Kariyerizm-işten ayrılma niyeti ilişkisinin istatistiksel açıdan anlamlı olmayışının bir sebebi olarak kariyeristlerin kariyerlerinde ilerlemeleri için istemedikleri davranışları da gösterebilecekleri ve bazen de sabırlı olabilecekleri gösterilebilir. Bu bulguya paralel olarak Ng vd. (2005)'in çalışmasında, profesyonellerin hiyerarşi basamaklarını daha kolay çıkabilmeleri için kıdem, tecrübe ve işe dair yetenekler geliştirmeleri gerektiğinden bahsetmişlerdir. Bu durumda işten ayrılma niyeti taşıyan çalışanların kariyerizm amacı gütsün veya gütmesin, işten ayrıldıklarında avantajı olabilmeleri için, bulundukları kurumda kıdem kazanma, yükselme gibi haklarını elde etmeleri gerekir. Bu sebeple kariyerizm eğilimindeki kişiler, bulundukları kurumda bir müddet daha kalmak ve yükselmek gibi eğilimlerinden dolayı ayrılma niyeti gütmeyebilirler. Ayrıca içinde bulunulan toplum kültürü (Abrams vd., 
1998; Hofstede, 2003) ve çalışma ortamı (çalışanların yetkinliği, örgüt atmosferi, örgütsel bağılık, adanmışlık, hizmet ekipmanının varlığı, hizmet programları ve iş tatmininin olması) (Maclntosh ve Doherty, 2010) da çalışanların işten ayrılma niyetlerini törpüleyen faktörler olarak gösterilebilir. Özellikle toplulukçu kültürlerde işten ayrılma niyetlerinin toplum içindeki öznel olarak algılanan normlar sebebiyle baskılandığı söylenebilir (Abrams vd., 1998).

Çalışma kurumlar, insan kaynakları yöneticileri ve uygulayıcılar açısından bazı çıkarımlar sunmaktadır. Kurumların kariyerist eğilime sahip ve ZVD sergileyen çalışanlardan kaynaklanan maliyetleri minimuma indirmesi şirket için verimlilik ve etkinliği istenen seviyelere taşıyabilecektir. Diğer yandan insan kaynakları yöneticilerinin işe alma, seçme ve yerleştirme faaliyetlerinde rutin olarak uygulamış oldukları kişilik testlerinde kariyerizm eğilimini de göz önüne almaları yerinde olacaktır. Çünkü bu durum kurumların belirtilen davranışlara karşı farkındalık kazanmasını sağlayacaktır. Son olarak işten ayrılma niyeti düşük olan çalışanların kurum içinde kalmaları için gerekli örgütsel bağlıık, psikolojik sahiplik, işe adanmışıı gibi tutumların oluşması sağlanmalıdır. Buna ek olarak bu kişilerin zorunlu vatandaşlık davranışlarından ziyade örgütsel vatandaşlık davranışlarını sergilemeye teşvik edecek bir kurumsal iklim tesis edilmelidir. Buna paralel olarak, kurumların, çalışanlarının ihtiyaçlarına yönelik kariyerlerini yapılandırmada öncü olması ve tüm bu süreçleri adil olarak gerçekleştirmeleri yerinde olacaktır. Çünkü bu tip önlemler kariyerizm gibi eğilimlerin önlenmesi ve çalışanların örgütsel bağlılıklarının geliştirilmesi açısından önemlidir (Crawshaw vd., 2012).

Her bireyin kişilik yapısının kendine özgü olduğu gibi, kariyer ihtiyaçları ve hedeflerinin de kendilerine özgü olduğu söylenebilir. Bu yüzden kurumların genelleştirilmiş, genel-geçer politikalarla değil, özellikle kendileri için önemli konumlarda olan yetenekleri kazanmak adına özelleşmiş kariyer gelişim planları yapmalarının çalışanlarının tatmin ve bağlıık seviyelerini arttıracağı düşünülmektedir. Bu tartışmalar ışı̆̆ında bir kez daha şunu belirtmekte fayda var; herhangi bir iş için gerekli nitelikler yanında çalışılan kurumun değerlerine, kültürüne ve ortamına uyumlu olmak da bir o kadar önemlidir (Lauver ve Kristof-Brown, 2001). Trevino vd. (1999) araştırmasında da görüldüğü üzere, çalışanlara yaklaşımlarını ve iletişimlerini değerler üzerine kuran kurumlar, uyum göstermeyi destekleyen kurumlara göre daha olumlu sonuçlar elde etmektedirler. Bu bağlamda ÖVD gibi değer temelli kültürlerin, çalışanların kendilerini başarılı hissetmek için dışsal ödüllere duyduğu ihtiyacı azalttğı görülmektedir (Yam vd., 2017). Bu sebeple, ÖVD'nin kurum için değerli ve faydalı olmasını isteyen profesyonellerin ÖVD’nin hakiki manasını ortaya çıkartan bir kurum kültürü inşa etmek üzere çaba göstermeleri önerilmektedir (Yam vd., 2017). Böylelikle etik kuralların ihlal edilmesine sebebiyet veren kariyerist kişilerin kendi çıkarlarını takip eden yaklaşımlarının azalması söz konusu olabilecektir.

Birçok araştırmada olduğu gibi bu çalışmanın da güçlü teorik altyapısı ve kapsamlı alanyazın taramasına rağmen çeşitli sınırlılıkları mevcuttur. Ancak bu sınırlılıklardan bahsetmeden önce şunu belirtmekte fayda var; ilgili sınırlılıklar sonraki araştırmacılar için bir başlangıç noktası teşkil etmekle beraber yeni araştırmaların yapılması konusundaki itici güçler olarak düşünülebilir. Araştırma kapsamında tespit edilen kısıtlar ve bu kısıtlar için önerilen gelecek araştırma konuları şöyledir;

Feldman ve Klich'in (1991) belirttiği üzere kariyerist eğilimdeki çalışanların takım oyuncusu gibi görünüp gerektiğinde kuruma ya da çalışanlarına zarar vermeyi kariyer ilerlemesi için doğal karşılama gibi olumsuz eğilimlerde de bulunabilmeleri mümkündür. Bu ifadeden hareketle gelecekteki araştırmaların kurumlarda önemli bir problem olan sosyal kaytarma davranışları ile kariyerizm arasındaki ilişkiyi incelemesi önerilmektedir. Ilgın'ın (2013:238) belirttiği üzere “sosyal kaytarma, bireylerin ortaklaşa çalıştiklarındaki motivasyon ve çabalarının, bireysel çalışmalarındakine göre azalması durumudur". Özellikle kariyeristlerin performansa dayalı olmayan yol ve yöntemlerle kariyer hedeflerine ulaşmak istedikleri düşünüldüğünde, bu kişilerin performanslarının net bir şekilde ölçülemediği grup, takım ya da kurumlarda daha fazla kariyerist eğilim ve sosyal kaytarma davranışları sergileme potansiyeli olabileceği düşünülmektedir. Bu bağlamda kariyerizm ile sosyal kaytarma davranışları arasındaki ilişkinin incelenmesi bir başka araştırma konusu olarak gelecek araştırmacılara önerilmektedir. 
Kariyerizm eğilimli çalışanların yaşadığı bir diğer durum ise kendi kişisel amaçları ile kurumun amaçları arasında kalmaları ve dengesizlik yaşamalarıdır (Chay ve Aryee, 1999; Feldman ve Weitz, 1991; Chibauru vd., 2013). Bu durum kurum genelindeki amaç ve hedefleri kendi amaç ve hedeflerine uyum sağlayacak şekilde yönetme eğilimi olan dönüşümcü liderlik (Robbins ve Judge, 2013) ile birlikte irdelendiğinde ortaya ilginç sonuçlar çıkabileceği düşünülmektedir. Başka bir ifadeyle çalışanların dönüşümcü liderlik algılarının çalışanların kariyerist eğilimlerini minimize etmede etkili olacağı öngörülmektedir.

Etik kodların belirsiz olduğu, güven ortamının sağlanamadığı ve belirsizlik toleransı düşük olan kişilerin kariyerizm eğilimi daha fazla olabilmektedir (Chay ve Aryee, 1999). Bu bağlamda kurum içerisinde etik kodların belirgin olduğu, baskın etik ilkelerin sürekli olarak çalışanlara hatırlatıldığı ve etik iklimin tüm çalışanlar tarafindan paylaşıldığı bir çalışma ortamının kariyerist eğilimleri engelleyeceği dolayısıyla da zorunlu vatandaşlık davranışlarının en aza indirileceği düşünülmektedir.

Kariyerizmin en önemli boyutlarından biri izlenim yönetimidir (Chibauru vd., 2013). İzlenim yönetimi bireyin çevresine kendi istediği şekilde görünebilmek için kendisi hakkındaki bilgileri manipüle etmesidir (Schlenker, 1980). Tek amacı diğerleri üzerinde bıraktı̆ı etkiyi yönetmek olan bu tip çalışanların, sosyal bağlar inşa edip ilişki kurmak yerine kendilerini nesneleştirdikleri için yabancılaşma yaşamaları ve dolayısıyla gerek performanslarını gerekse örgütsel bağılıklarını düşürmeleri kuvvetle muhtemeldir (Chiaburu vd., 2013). Kariyerizm eğilimi olan bir çalışan aslında içten içe kendisine "tüketilebilir bir nesne" olarak yaklaşmaktadır ve bu da bir insanın bulunduğu ortama ve en kötüsü de kendine en çabuk ve güçlü şekilde yabancılaşmasını sağlayabilecek unsurların başında gelmektedir (Feldman ve Klich, 1991; Feldman ve Weitz, 1991).Yukarıdaki açıklamalar ışı̆̆ı altında İzlenim yönetimi açısından izlenim yönetimi taktiklerinden hangilerinin kariyerizm ile ilişkili olabileceğinin tespit edilmesi bir başka araştırma konusu olarak gelecek araştırmacılara önerilmektedir.

Hofstede (2003)'nin kültür boyutları düşünüldüğünde (bireyci-toplumcu, erillik-dişilik, belirsizliğe tölerans, güç mesafesi, uzun ve kısa döneme yönelme) güç mesafesinin yüksek olduğu, eril, belirsizliği tölerans olmayan, kısa döneme odaklı ve bireyci topluluklarda kariyerist eğilimlerin daha fazla olacağı düşünülmektedir. Bu bağlamda Kültür araştırmalarının kariyerizm ile ilişkisinin ortaya konulması yine farklı araştırmalarca dikkate alınabilir.

Yıldız vd. (2015)'in yapmış oldukları çalışmanın bulguları değerlendirildiğinde her ne kadar kariyerizm eğiliminin bireyler arası ve kuruma karşı sapkın iş yeri davranışları ile olumlu yönde ilişkili olması beklenen bir sonuç olsa da bu eğilimin yapıcı sapkın iş yeri davranışlarının alt boyutlarından biri olan meydan okuyucu yapıcı sapkın iş yeri davranışları ile olumlu yönde ilişkili olması dikkat çekmektedir. Bu bağlamda kariyerizm eğiliminin potansiyel sonuçlarının tamamen olumsuz değişkenlere odaklanmaktansa olumlu değişkenlerle de ilişkili olabileceği ya da olumlu sonuçlara sebep olmasını sağlayan şartlı değişkenlerin tespit edilmesinin alanyazındaki gri alanları netleştireceği düşünülmektedir.

Araştırmamızın en önemli kısıtlarından bir diğeri ise şartlı etkilerden sadece işten ayrılma niyetinin kullanılmış olmasıdır. Kişilik yapısı, güven algısı gibi kişisel durumsal etkilerin yanı sıra kurum kültürü, kurum atmosferi, belirsizlik düzeyi gibi birçok örgütsel durum da kariyerizm için etkili olabilmektedir. Bu etkilere de bakılması gelecekte yapılacak olan araştırmalar için faydalı olabilir.

Ayrıca, çalışanların iş güvencelerinin azaldığı ve yönetimin kendilerine nasıl bir tutum ve davranış içinde olacağını bilmedikleri çalışma şartlarında da kariyerist bir eğilim sergiledikleri gözlemlenmiştir (Chay ve Aryee, 1999). Her ne kadar zorunlu vatandaşlık davranışlarının örgütsel ya da yönetsel baskı ya da zorlamalar ile ilgili olduğuna değinilse de (Vigoda-Gadot, 2007; 2006) bu çalışmada olduğu gibi kariyerizm gibi birey düzeyindeki öncüllerin tespit edilmesinin, fotoğrafin bütününün anlaşılması açısından faydalı olacağı düşünülmektedir. Bu bağlamda Yıldız vd., (2017)'nin çalışmalarındaki ilginç bir bulgu olumlu olarak kabul edilen ancak bazen olumsuz sonuçlara da sebep olabilecek bazı kişilik özelliklerine dikkat çekmektedir. Belirtilen çalışmada alanyazında olumlu bir kişilik özelliği olarak bilinen sorumluluk kişilik özelliğinin bazen örgüt tarafindan olumsuz olarak kabul edilen sözde var olma (presenteeism) gibi çeşitli davranışlara sebep oldu bulgulanmıştır. Bu kişilerin örgüt tarafindan istenmeyen davranışları görevlerinin bir parçası olarak görme ya da kurumun amaçlarını gerçekleştirmek için kendilerini feda etme eğiliminde oldukları söylenebilir. Bu bağlamda zorunlu vatandaşlık davranışları ile kişilik özellikleri arasındaki ilişkinin incelenmesi ve 
kariyerizmin hangi kişilik özelliği ile nasıl ilişkili olduğunun tespit edilmesi bir başka araştırmanın konusu olabilir.

Son olarak sosyal bilimlerin doğası ve insan yapısının karmaşıklığı göz önüne alındığında yapılan çalışmaların resmin sadece belirli bir kısmını açıklamakta yeterli olduğu durumu ortaya çıkmaktadır. Bu bağlamda özellikle bu çalışmanın daha büyük örneklemler üzerinde ve farklı meslek grupları üzerinde yapılması araştırma sonuçlarının genellenebilmesi açısından önem arz etmektedir. Her ne kadar şartlı değişken etkisini belirlemeye yönelik olan bu çalışmanın ilgili alanyazındaki boşluğu doldurma yönünde bir katkı sağladığı düşünülse de kariyerist kişilerin nasıl zorunlu vatandaşlık davranışları yapmaya motive olduklarını açıklayacak öz yeterlilik, kişi-örgüt uyumu, kişi-iş uyumu, psikolojik sahiplik, izlenim yönetimi taktikleri gibi potansiyel ara değişkenlerin (mediator) test edilmesi gelecek araştırmacılara önerilmektedir.

\section{Kaynaklar}

Abrams, D., Ando, K., \& Hinkle, S. (1998). Psychological attachment to the group: Cross-cultural differences in organizational identification and subjective norms as predictors of workers' turnover intentions. Personality and Social Psychology Bulletin, 24(10), 1027-1039.

Adams, J. W. (2011). Examination of inter-relationships between psychological contract, careerist orientation, and organizational citizenship behaviour. Doctoral dissertation. City University. London.

Aiken, L. S., West, S. G., \& Reno, R. R. (1991). Multiple regression: Testing and interpreting interactions. Newbury Park, CA: Sage

Alkan, S. E., \& Turgut, T. (2015). A research about the relationship of psychological safety and organizational politics perception with compulsory citizenship behavior and the pressures behind compulsory citizenship behavior. Research Journal of Business and Management, 2(2), 185-203.

Aryee, S., \& Chen, Z. X. (2004). Countering the trend towards careerist orientation in the age of downsizing: test of a social exchange model. Journal of Business Research, 57(4), 321-328.

Bandura, A. (1986). Social foundations of thought and action: A social cognitive theory. Englewood Cliffs, NJ: PrenticeHall.

Bandura, A., Barbaranelli, C., Caprara, G. V., \& Pastorelli, C. (1996). Mechanisms of moral disengagement in the exercise of moral agency. Journal of Personality and Social Psychology, 71(2), 364-374.

Bandura, A. (1999). Moral disengagement in the perpetration of inhumanities. Personality and Social Psychology Review, 3(3), 193-209.

Baruch, Y. (2004). Managing careers: Theory and practice. Harlow, England: Prentice Hall

Blau, G., Merriman, K., Tatum, D.S., \& Rudman, S.V. (2001). Antecedents and consequences of basic versus career enrichment benefit satisfaction. Journal of Organizational Behavior, 22: 6, 669-688.

Bolino, M. C., Turnley, W. H., Gilstrap, J. B., \& Suazo, M. M. (2010). Citizenship under pressure: What's a "good soldier" to do? Journal of Organizational Behavior, 31(6), 835-855.

Bolino, M. C., Klotz, A. C., Turnley, W. H., \& Harvey, J. (2013). Exploring the dark side of organizational citizenship behavior. Journal of Organizational Behavior, 34(4), 542-559.

Brislin, R. W. (1970). Back-translation for cross-cultural research. Journal of Cross-Cultural Psychology, 1(3), 185-216.

Bratton, V. K., \& Kacmar, K. M. (2004). Extreme careerism: The dark side of impression management. (Ed.) Griffin R. W., O'Leary-Kelly A.The dark side of organizational behavior, 291-308. San Fransisco: John Wiley \& Sons.

Chay, Y. W., \& Aryee, S. (1999). Potential moderating influence of career growth opportunities on careerist orientation and work attitudes: Evidence of the protean career era in Singapore. Journal of Organizational Behavior, 613623.

Chen, X. P., Hui, C., \& Sego, D. J. (1998). The role of organizational citizenship behavior in turnover: Conceptualization and preliminary tests of key hypotheses. Journal of Applied Psychology, 83(6), 922.

Chiaburu, D. S., Oh, I.-S., Berry, C. M., Li, N., \& Gardner, R. G. (2011). The five-factor model of personality traits and organizational citizenship behaviors: A meta-analysis. Journal of Applied Psychology, 96(6), 1140-1166

Chiaburu, D. S., Diaz, I., \& De Vos, A. (2013). Employee alienation: relationships with careerism and career satisfaction. Journal of Managerial Psychology, 28(1), 4-20. 
İyi Bir Asker Mi? İyi Bir İlüzyonist Mi? Kariyerizm ile Zorunlu Vatandaşlık Davranışları Arasındaki İlişkide İşten Ayrılma Niyetinin Rolü

Cohen, J., Cohen, P., West, S. G., \& Aiken, L. S. (2013). Applied multiple regression/correlation analysis for the behavioral sciences. Routledge.

Crawshaw, J. R., Van Dick, R., \& Brodbeck, F. C. (2012). Opportunity, fair process and relationship value: career development as a driver of proactive work behaviour. Human Resource Management Journal, 22(1), 4-20.

Cronbach, L. J. (1951). Coefficient alpha and the internal structure of tests. Psychometrika, 16(3), 297-334.

Dalal, R. S. (2005), A Meta-Analysis of the Relationship between Organizational Citizenship Behavior and Counterproductive Work Behavior, Journal of Applied Psychology, 90(6), 1241-1255.

Egan, T. M., Yang, B., \& Bartlett, K. R. (2004). The effects of organizational learning culture and job satisfaction on motivation to transfer learning and turnover intention. Human Resource Development Quarterly, 15(3), $279-301$.

Feldman, D. C., \& Klich, N. R. 1991. Impression management and career strategies. In R. A. Giacalone \& P. Rosenfeld (Eds.), Applied impression management: How imagemaking affects managerial decisions: 67-80. Newbury Park, CA: Sage.

Feldman, D. C., \& Weitz, B. A. (1991). From the invisible hand to the gladhand: Understanding a careerist orientation to work. Human Resource Management, 30(2), 237-257.

Griffeth, R. W., \& Hom, P. W. (1995). The employee turnover process. Research in personnel and Human Resources Management, 13(3), 245-293.

Hayes, A. F. (2012). PROCESS: A versatile computational tool for observed variable mediation, moderation, and conditional process modeling [White paper]. 2012. URL: http://imaging. mrc-cbu. cam. ac. uk/statswiki/FAQ/SobelTest.

Hayes, A. F. (2013). Introduction to mediation, moderation, and conditional process analysis: A regression-based approach. Guilford Press. New York, ABD.

Hofstede, G. (2003). Culture's consequences: Comparing values, behaviors, institutions and organizations across nations. Thousand Oaks, California: Sage publications.

IIgın, B. (2013). Toplumsal bir hastalık: Sosyal kaytarma. Uşak Üniversitesi Sosyal Bilimler Dergisi, 6, 3

Irving, P. G., Coleman, D. F., \& Cooper, C. L. (1997). Further assessments of a three-component model of occupational commitment: Generalizability and differences across occupations. Journal of Applied Psychology, 82(3), 444.

Johansen, S. M., \& von Treuer, K. (2012). An examination of psychological contracts, careerism and intention to leave. Career Development International, 17(5), 475-494.

Karataş, A. (2013). Bankacılık Sektöründe Cinsiyete Dayalı Kariyer Farklılaşması: Muğla ilii Örneği. Organizasyon ve Yönetim Bilimleri Dergisi, 5(2), 1-18.

Koopman, J., Lanaj, K., \& Scott, B. A. (2016). Integrating the bright and dark sides of OCB: A daily investigation of the benefits and costs of helping others. Academy of Management Journal, 59(2), 414-435.

Kraimer, M. L., Seibert, S. E., Wayne, S. J., Liden, R. C., \& Bravo, J. (2011). Antecedents and outcomes of organizational support for development: the critical role of career opportunities. Journal of Applied Psychology, 96(3), 485.

Kreft, I. G., De Leeuw, J., \& Aiken, L. S. (1995). The effect of different forms of centering in hierarchical linear models. Multivariate Behavioral Research, 30(1), 1-21.

Lauver, K. J., \& Kristof-Brown, A. (2001). Distinguishing between employees' perceptions of person-job and personorganization fit. Journal of Vocational Behavior, 59(3), 454-470.

Lee, T. W., \& Mowday, R. T. (1987). Voluntarily leaving an organization: An empirical investigation of Steers and Mowday's model of turnover. Academy of Management Journal, 30(4), 721-743.

LePine, J. A., Erez, A., \& Johnson, D. E. (2002). The Nature and Dimensionality of Organizational Citizenship Behavior: A Critical Review and Meta-Analysis. Journal of Applied Psychology, 87(1), 52.

Liu, Y., Chen, Y. J., \& Wang, L. C. (2017). Family business, innovation and organizational slack in Taiwan. Asia Pacific Journal of Management, 34(1), 193-213.

Macintosh, E. W., \& Doherty, A. (2010). The influence of organizational culture on job satisfaction and intention to leave. Sport Management Review, 13(2), 106-117.

Meyer, J. P., Stanley, D. J., Herscovitch, L., \& Topolnytsky, L. (2002). Affective, continuance, and normative commitment to the organization: A meta-analysis of antecedents, correlates, and consequences. Journal of Vocational Behavior, 61(1), 20-52.

Mobley, W. H., Griffeth, R. W., Hand, H. H., \& Meglino, B. M. (1979). Review and conceptual analysis of the employee turnover process. Psychological Bulletin, 86, 493-522. 
Morrison, E. W. 1994. Role definitions and organizational citizenship behavior: The importance of the employee's perspective. Academy of Management Journal, 37: 1543-1567.

Ng, T. W. H., Eby, L. T., Sorensen, K. L., \& Feldman, D. C. (2005). Predictors of objective and subjective career success: A meta-analysis. Personnel Psychology, 58, 367-408.

Nunnally, J.C., \& Bernstein, I.H., (1994). Psychometric Theory, 3rd ed. New York: McGraw-Hill, Inc.

Organ, D. W. (1988), Organizational Citizenship Behavior: The Good Soldier Syndrome, Canada: Lexington Books.

Organ, D. W. (1990). The Motivational Basis of Organizational Citizenship Behavior. Research in Organizational Behavior, 12(1), 43-72.

Organ, D. W. (1997), Organizational Citizenship Behavior: It's Construct Clean-Up Time, Human Performance, 10(2), 8597.

Organ, D. W., \& Konovsky, M. A. (1989), Cognitive Versus Affective Determinants of Organizational Citizenship Behavior, Journal of Applied Psychology, 74(1). 157-64.

Organ, D. W., \& Ryan, K. (1995), A Meta-Analytic Review of Attitudinal and Dispositional Predictors of Organizational Citizenship Behavior, Personnel Psychology, 48(4), 775-802.

Organ, D. W., \& Lingl, A. (1995). Personality, Satisfaction, and Organizational Citizenship Behavior. The journal of Social Psychology, 135(3), 339-350.

Podsakoff, P. M., MacKenzie, S. B., Moorman, R. H., \& Fetter, R. (1990). Transformational Leader Behaviors and Their Effects on Followers' Trust in Leader, Satisfaction, and Organizational Citizenship Behaviors. The Leadership Quarterly, 1(2), 107-142.

Podsakoff, P.M., \& MacKenzie, S.B. (1994). Organizational citizenship and sales unit effectiveness. Journal of Marketing Research, 3(3), 351-363.

Podsakoff, N. P., Whiting, S. W., Podsakoff, P. M., \& Blume, B. D. (2009). Individual-and Organizational-Level Consequences of Organizational Citizenship Behaviors: A Meta-Analysis. Journal of Applied Psychology, 94(1), 122.

Robbins, S. P., \& Judge, T. A. (2013). Organizational Behavior Global. New Jersey: Pearson.

Salamon, S. D., \& Deutsch, Y. 2006. OCB as a handicap: An evolutionary psychological perspective. Journal of Organizational Behavior, 27: 185-199

Schlenker, B. R. (1980). Impression management. Monterey: Brooks/Cole Publishing Company.

Schwepker, C. H. (2001). Ethical climate's relationship to job satisfaction, organizational commitment, and turnover intention in the salesforce. Journal of Business Research, 54(1), 39-52.

Smith, C. A., Organ, D. W., \& Near, J. P. (1983), Organizational Citizenship Behavior: Its Nature and Antecedents, Journal of Applied Psychology, 68(4), 653-663.

Stone, E. F., \& Hollenbeck, J. R. (1989). Clarifying some controversial issues surrounding statistical procedures for detecting moderator variables: Empirical evidence and related matters. Journal of Applied Psychology, 74(1), 3.

Şeşen, H., \& Soran, S. (2013). Örgütsel Vatandaşlıktan Zorunlu Vatandaşlığa: Zorunlu Vatandaşlık Davranışının Bazı Faktörlerle İlişkisi. 21. Yönetim e Organizasyon Kongresi Bildiriler Kitabı. 407-410.

Tett, R. P., \& Meyer, J. P. (1993). Job satisfaction, organizational commitment, turnover intention, and turnover: path analyses based on meta-analytic findings. Personnel Psychology, 46(2), 259-293.

Trevino, L. K., Weaver, G. R., Gibson, D. G., \& Toffler, B. L. (1999). Managing ethics and legal compliance: What works and what hurts. California Management Review, 41(2), 131-151.

Vigoda-Gadot, E. R. A. N. (2006). Compulsory Citizenship Behavior: Theorizing Some Dark Sides of the Good Soldier Syndrome in Organizations. Journal for the Theory of Social Behaviour, 36(1), 77-93.

Vigoda-Gadot, E. (2007). Redrawing the Boundaries of OCB? An Empirical Examination of Compulsory Extra-Role Behavior in the Workplace. Journal of Business and Psychology, 21(3), 377-405.

Walumbwa, F. O., Hartnell, C. A., \& Oke, A. (2010). Servant Leadership, Procedural Justice Climate, Service Climate, Employee Attitudes, and Organizational Citizenship Behavior: A Cross-Level Investigation. Journal of Applied Psychology, 95(3), 517.

Yam, K. C., Klotz, A. C., He, W., \& Reynolds, S. J. (2017). From good soldiers to psychologically entitled: Examining when and why citizenship behavior leads to deviance. Academy of Management Journal, 60(1), 373-396.

Yıldız, B., Yıldiz H., \& Alpkan L. (2015). Olağandışı İşyeri Davranışlarının Bir Öncülü Olarak Kariyerizm, 3. Örgütsel Davranış Kongresi, TOKAT, TÜRKIYE, 6-7 Kasım 2015, cilt.3, no.1, ss.684-689 
Yıldız, B. (2015). The Antecedents of Constructive and Destructive Deviant Workplace Behaviors. Unpublished Doctoral Dissertation, Kocaeli: Gebze Technical University.

Yıldız, B., \& Alpkan, L. (2015). A Theoretical Model on the Proposed Predictors of Destructive Deviant Workplace Behaviors and the Mediator Role of Alienation. Procedia-Social and Behavioral Sciences, 210, 330-338.

Yıldız, B., Yıldız, H., \& Alpkan, L. (2015). Olağandışı İşyeri Davranışlarının Bir Öncülü Olarak Kariyerizm. 3. Örgütsel Davranış Kongresi, 6-7 Kasım, Tokat.

Yildiz H., Yildiz B., Zehir C., Altindağ E., Moloğlu V., \& Kitapçı H. (2017). "Impact On Presenteeism Of The Conscientiousness Trait: A Health Sector Case Study", Social Behavior And Personality, 5,399-411.

Zhao, H., Peng, Z., Han, Y., Sheard, G., \& Hudson, A. (2013). Psychological Mechanism Linking Abusive Supervision and Compulsory Citizenship Behavior: A Moderated Mediation Study. The Journal of Psychology, 147(2), 177-195.

Zhao, H., Peng, Z., \& Chen, H. K. (2014). Compulsory Citizenship Behavior and Organizational Citizenship Behavior: The Role of Organizational Identification and Perceived Interactional Justice. The Journal of Psychology, 148(2), 177196.

Ziegler, R., Schlett, C., Casel, K., \& Diehl, M. (2012). The Role of Job Satisfaction, Job Ambivalence, and Emotions At Work in Predicting Organizational Citizenship Behavior. Journal of Personnel Psychology. 11 (4), 176-190. 


\section{Ekler}

\section{Ek 1: Araştırmada Kullanılan Ölçekler;}

\section{Işsten Ayrılma Niyeti Ölçeği}

IAN1 Yakın gelecekte işimi değiştirme niyetindeyim.

IAN2 Muhtemelen önümüzdeki yıl içinde yeni bir iş bakacağım.

IAN3 Yakın gelecekte bu işte kalma niyetinde değilim.

\section{Zorunlu Vatandaşlık Davranışları Ölçeği}

ZVD1 Bu kurumun yönetimi, resmi görev tanımları kapsamında olmayan ek görevleri yerine getirmeleri için çalışanlarına baskı yapmaktadır.

ZVD2 Bu kurumda, resmi iş yükünün dışında ve herhangi bir resmi karşılığı olmaksızın, fazla mesai yapılması konusunda sosyal baskı vardır.

ZVD3 Bu işte yasal iş gereklerim ve istediğim dışında fazla çaba harcamam yönünde bir beklenti olduğunu hissediyorum.

ZVD4 Yeterli zamanım veya enerjim olmadığında dahi, resmi yükümlülüklerim kapsamında olmamasına rağmen diğer çalışanlara yardımcı olmaya zorlandığımı hissediyorum.

ZVD5 İşimin resmi gereklilikleri kapsamında olmamasına rağmen, iradem dışında yöneticime yardımcı olmaya zorlandığımı hissediyorum.

\section{Kariyerizm Ölçeği}

KR1. Kurumlar içerisinde yalnızca liyakat ile ilerlemek zordur.

KR5. Yükselmek için genellikle üstler, çalışma arkadaşları ve diğer arkadaşlar ile sosyal ilişkilerden faydalanılması gereklidir.

KR2. Başarılılık imajından istifade edilmesi önemlidir, zira başarılıymış gibi görünmek, ilerleme kaydedilmesi konusunda yetkinlik kadar etkili olabilir.

KR3. Bazen, kişinin hak ettiğini düşündüğü terfiyi alabilmesi için yanıltıcı davranışlar sergilemesi gerekir.

*KR5. Uzun vadede bireyin kariyer hedefleri kurumun çıkarları ile örtüşmeyebilir; nihayetinde herkes kendi çıkarlarına hizmet eder.

KR6. İşverene sadakat ödüllendirilmez

*KR7. İlerleme kaydedilebilmesi için, bazen kurumun menfaatlerinden ziyade kişisel gelişimi destekleyen eylemlerde bulunulması gerekir.

* Faktör analizinde uygun faktöre dağılmadığı için analizden çıkarılan soruları göstermektedir. 
This Page Intentionally Left Blank 